\title{
Economic Consequences Of IFRS Adoption In Korea: A Literature Review
}

\author{
Jee In Jang, Chung-Ang University and Korea Accounting Standards Board, Republic of Korea \\ Kyung Joo Lee, University of Maryland at Eastern Shore, U.S.A \\ Youngmi Seo, Korea Accounting Standards Board, Republic of Korea \\ Joonhei Cheung, Daegu University, Republic of Korea
}

\begin{abstract}
We provide a comprehensive review of academic research on the economic consequences of International Financial Reporting Standards (IFRS) adoption in Korea. We review 18 empirical studies on the economic consequences of IFRS adoption in Korea and classify them into six areas: (a) earnings quality, (b) comparability of financial statements, (c) value relevance, (d) analysts' behavior, (e) information asymmetry, and (f) cost of capital and firm value. Our review suggests that IFRS adoption in Korea has generally afforded positive economic consequences. The limitations of the existing studies are discussed and various directions for future research are suggested.
\end{abstract}

Keywords: IFRS; Korea; Earnings Quality; Costs of Capital; Economic Consequences

\section{INTRODUCTION}

Qf ince its first adoption by European Union (hereafter, EU) in 2005, numerous countries, including South Korea (hereafter, Korea), Australia, New Zealand, Singapore, Hong Kong and Philippines, have adopted International Financial Reporting Standards (hereafter, IFRS). As of April 2015, around 115 countries have adopted IFRS and another are contemplating its introduction ${ }^{l}$. Within a decade, IFRS have become the global accounting standards used by more than half of all countries. The International Accounting Standards Board (hereafter, IASB) argues that the worldwide expansion of IFRS would promote internationally united accounting standards and satisfy globalized capital market needs.

Along with the expansion of IFRS around the world, many academic studies have examined the effects of IFRS adoption on accounting information quality and economic consequences in capital market setting. Most of these studies have been conducted on European countries or Australia, which were the first generation adopters of IFRS. Recently, however, efforts have increased to examine the effects of IFRS adoption in other countries such as Canada and Korea.

Most empirical studies have shown the positive economic effects of IFRS adoption such as an increase in accounting information quality and a decrease in cost of capital. These results are consistent across the periods of IFRS adoption and different jurisdictions (Barth et al. 2008; Armstrong et al. 2012). However, some research papers report negative effects or statistically insignificant results of IFRS adoption (Capkun et al. 2008; Ahmed et al. 2012). Recent studies provide evidence that the effects of IFRS adoption vary across countries (Houqe et al. 2012; Cascino and Gassen, 2015). These studies argue that the effects of IFRS adoption could be affected by cultural factors, the gap between IFRS and local Generally Accepted Accounting Principles (hereafter, GAAP), enforcement levels, and transparency and the accounting quality of each country. ${ }^{2}$

\footnotetext{
${ }^{1}$ According to the profiles analysis by the IFRS foundation, as of April 2015, 116 countries (83\%) out of 140 jurisdictional profiles require listed companies within the jurisdiction to apply IFRS.

${ }^{2}$ For example, Soderstrom and Sun (2007) argued that cross-country differences in accounting quality are likely to remain following IFRS adoption because accounting quality is a function of the firm's overall institutional setting, including the legal and political system of the country in which the firm resides.
}

Copyright by author(s); $\underline{\mathrm{CC}-\mathrm{BY}}$ 
In an attempt to provide further insight into the effects of IFRS adoption, this study presents a comprehensive review of academic research on the economic consequences of IFRS adoption in Korea, which is viewed as a representative country among the second generation adopters of IFRS. Korea fully adopted IFRS in 2011 and required all listed companies and financial institutions to mandatorily apply IFRS. Korea is distinct from the first generation adopters of IFRS such as European countries and Australia in that it had been using rule-based accounting standards and there is a large gap between IFRS and local Korean GAAP (hereafter, K-GAAP) (Bae et al. 2008).

This study promises to make the following contributions to the accounting literature on economic consequences of IFRS adoption. First, K-GAAP is typical "rule-based" accounting standards and thus distinctively different from IFRS, which is considered "principle-based" accounting standards. That is, the effects of IFRS adoption can be more clearly observed as it is likely to have induced huge changes in accounting standards, as well as in the whole economy, in Korea compared with those of Europe or Australia, which basically used principle-based accounting standards. Second, Korean accounting culture is different from that of member countries of the Commonwealth. Therefore, it may take a significant amount of time for IFRS adoption to have economic effects in Korea. Now that four years have passed since IFRS adoption, a review of the literature on the economic consequences of IFRS adoption and its implementation will provide meaningful implications. Third, Korea fully adopted IFRS with a Big-Bang approach in 2011 and required all listed companies and financial institutions to apply IFRS. Unlike other countries which decided to modify or carve-out a part of IFRS, Korea did not allow carve-outs from IFRS. The Korean government initiated IFRS adoption following four years of preparatory period. Therefore, we expect that the approaches to and the preparation process for IFRS adoption may have different economic consequences of IFRS adoption in Korea ${ }^{3}$.

This paper proceeds as follows. The IFRS adoption process in Korea and comparison between IFRS and K-GAAP are discussed in the next section. Section 3 reviews empirical studies on IFRS adoption in Korea by categorizing them into six areas. Section 4 summarizes the results and implications, and provides some suggestions for future research.

\section{BACKGROUND}

\section{The IFRS Adoption Process in Korea}

In 2007, Korea decided to adopt IFRS for all Korean companies (allowing voluntary early adoption from 2009) from 2011 as part of the effort to improve the accounting transparency and to demonstrate Korea's strong willingness to take part in the international efforts aimed at instigating a single set of high-quality global accounting standards which are expected to mitigate the so-called 'Korea discount' phenomenon (KASB 2012). The following are the two primary incentives for full adoption of IFRS in Korea.

First, alarmed by the East Asian financial crisis in 1997, Korea wanted to improve domestic and foreign investors' perception on the transparency of financial statements provided by Korean companies. Therefore, an independent private-sector accounting standard setting organization, Korea Accounting Institute (KAI), was established to improve Korean GAAP to the level of the International standards. However, the assessment by the international community on the transparency of Korean financial statements did not improve and so-called 'Korea discount' phenomenon persisted. ${ }^{4}$ This persistence necessitated further efforts to improve the level of trust in accounting information by taking actions to enhance the quality of accounting standards, which led to the full adoption of IFRS by the Korean government (KASB 2012).

Second, another motivation for IFRS adoption was an active response to the global trend of 'convergence of accounting standards'. The demand for global accounting standards had become very strong by March 2007, when more than 100 countries, including Australia, Hong Kong and Canada, either adopted or were about to adopt IFRS following the EU. Korea, a small open economy that heavily depends upon international trades, actively tried to accommodate this global trend.

\footnotetext{
${ }^{3}$ Korea chose to employ a Big-Bang approach in adopting full IFRS instead of taking the phased-in or convergence approach.

${ }^{4}$ The term, 'Korea Discount', was used by Forbes Magazine to explain a kind of phenomenon that investors are underestimated the Korean stocks. (The Korea Times 2010).

Copyright by author(s); $\underline{\text { CC-BY }}$ 
Korea launched 'the IFRS Adoption Task Force' in February 2006 to discuss the issues and ideas for successful implementation of IFRS adoption. The Task Force announced 'the Roadmap toward IFRS adoption in Korea' (hereafter, 'Roadmap') in March 2007. According to the Roadmap, all the listed companies where required to adopt IFRS from 2011, while allowing them to adopt IFRS as early as 2009. However, financial institutions were not allowed early adoption.

To minimize the compliance costs, the Roadmap required Korean IFRS (hereafter, K-IFRS), a word-by-word translation of IFRS, to be ready by the end of 2007. Also included in the Roadmap was the requirement to amend the laws and regulations on the accounting and disclosure before the adoption in 2011. To remain consistent with the consolidated financial statements under IFRS, the Roadmap also required companies to prepare quarterly and semiannual consolidated financial reports from 2011. However, companies with total assets less than 2 trillion Korean won (hereafter, KRW) were allowed to have two additional years of preparation and report quarterly and semi-annual financial statements from 2013.

In March 2009, 'the IFRS Implementation Support Task Force' was established to deal with practical issues arising from early adoption companies and to support the stabilization of IFR adoption process. The IFRS Implementation Support Task Force operated until November 2010. In addition, the Korean government exerted every effort to prevent financial statement users' confusion over the implementation of IFRS by providing sufficient information on IFRS to the interest parties in capital markets and by requiring companies to disclose comparative financial statements before and after the IFRS adoption period. ${ }^{5}$ Table 2 summarizes the IFRS adoption process in Korea.

Table 1. The IFRS Adoption Process in Korea

\begin{tabular}{|c|c|c|c|}
\hline 2007 & 2009 & 2011 & 2013 \\
\hline $\begin{array}{l}\text { - The Roadmap announced } \\
\text { - K-IFRS endorsed }\end{array}$ & $\begin{array}{l}\text { Early-adoption of IFRS } \\
\text { (excluding financial } \\
\text { institutions) }\end{array}$ & $\begin{array}{l}\text { - Mandatory adoption of } \\
\text { IFRS (quarterly and half- } \\
\text { year reporting for } \\
\text { companies with total assets } \\
\text { greater than } 2 \text { trillion KRW) }\end{array}$ & $\begin{array}{l}\text { Quarterly and half-year } \\
\text { reporting for companies } \\
\text { with total assets less than } 2 \\
\text { trillion KRW) }\end{array}$ \\
\hline
\end{tabular}

(KASB 2012)

IFRS adoption in Korea comprised two distinctive features. First, Korea chose to employ a Big-Bang approach by adopting IFRS fully and at a specified point in time instead of taking the phased in or convergence approach. While the Big-Bang approach is less manageable than the convergence approach, the Korean government believed it to be the most suitable procedure and that it could demonstrate Korea's strong will to take part in the international movement towards a single set of high-quality global accounting standards. Second, the single tier accounting system of Korea (K-GAAP) was switched to a two-tier accounting system (IFRS and Accounting Standards for Non-Public Entities). To mitigate the problems associated with the trade-off between users and preparers, the Roadmap required IFRS to be applied to only listed companies and financial institutions where the demand on accounting transparency is very high among stakeholders. However, the Roadmap assumed that non-listed companies, the stakeholders of which are much narrower than those of listed companies, could avoid the IFRS compliance burden by applying Accounting Standards for Non-Public Entities. ${ }^{6}$

\footnotetext{
${ }^{5}$ Considering the significant effects that IFRS would have on the financial position and performance of companies, there was a need to require companies to provide the users of the financial statements with information relating to the effects of IFRS adoption on them in advance. Thus, 'the Financial Supervisory Service' issued a practical guideline in July 2007 recommending that companies disclose the effects of IFRS adoption in the notes to the financial statements, starting from two years prior to the adoption. Accordingly, companies were required to disclose preparation plans for IFRS adoption, the progress thereof and analysis of adoption effects beforehand.

${ }^{6}$ Early adoption of K-IFRS was made by 14 and 59 companies in 2009 and 2010, respectively. A total of 3,126 companies, including 1,783 listed companies, 201 unlisted financial companies and 1,142 unlisted companies, started mandatory adoption of K-IFRS. As of December 31, 2014, mandatory IFRS adopters were approximately 2,075.
}

Copyright by author(s); $\underline{\text { CC-BY }}$ 


\section{Difference Between IFRS and K-GAAP}

The considerable differences that exist between IFRS and K-GAAP are important because they can affect the extent of economic consequences of IFRS adoption. The major differences between IFRS and K-GAAP and their potential effects on economic consequences are summarized in Table 2.

Table 2. IFRS vs. K-GAAP

\begin{tabular}{l|l|l}
\hline \multicolumn{1}{c|}{ K-GAAP } & \multicolumn{1}{c}{ IFRS } & \multicolumn{1}{c}{ Expected Changes } \\
\hline Rule-based accounting standards & Principle-based accounting standards & Increased discretion by management \\
\hline $\begin{array}{l}\text { Separate financial statements as } \\
\text { primary financial statements }\end{array}$ & $\begin{array}{l}\text { Consolidated financial statements as } \\
\text { primary financial statements }\end{array}$ & $\begin{array}{l}\text { Enhanced comparability and value } \\
\text { relevance }\end{array}$ \\
\hline $\begin{array}{l}\text { Book value accounting with acquisition } \\
\text { cost basis }\end{array}$ & $\begin{array}{l}\text { Expansion of the scope of fair value } \\
\text { accounting }\end{array}$ & $\begin{array}{l}\text { Increased use of fair value } \\
\text { measurement }\end{array}$ \\
\hline $\begin{array}{l}\text { Relatively less detailed disclosures in } \\
\text { notes }\end{array}$ & Detailed disclosures in notes & $\begin{array}{l}\text { Improvement in quality and quantity of } \\
\text { disclosures in notes }\end{array}$ \\
\hline
\end{tabular}

First, K-GAAP is rule-based accounting standards while IFRS are principle-based accounting standards. Hence, IFRS induce the accountants to follow a rational accounting process based on the economic reality of specific situations rather than relying on a consistent and regularized accounting process. This difference has raised the issues of the mangers' discretion and their ability to adjust to the new accounting system.

Second, primary financial statements differ between K-GAAP and IFRS. In K-GAAP, primary financial statements are separate financial statements whereas consolidated financial statements are primary financial statements in IFRS. Korea put more emphasis on separate financial statements because unlike European firms, Korean firms have a complicated ownership structure and both subordinated and dominant companies are usually listed. Therefore, interesting issues are the investors' response to the separate financial statements and the relative importance of consolidated financial statements after the adoption of IFRS.

Third, they are different in fair value accounting. Whereas K-GAAP partly allows fair value accounting, IFRS require fair value accounting for most assets and liabilities. Thus, IFRS put more emphasis on relevance than on reliability. This fair value accounting with IFRS may result in less reliability compared to the book value accounting with acquisition cost basis in K-GAPP.

Lastly, the degree of disclosures in notes differs. IFRS require more detailed disclosures on financial statements due to the increased managers' discretion from applying principle-based accounting and the need to provide supplementary information. This results in more disclosures in notes and hence more burdens to the companies in preparing and auditing financial statements.

These differences between IFRS and K-GAAP could be relatively larger than those in European countries or Australia. Therefore, the implications from empirical research results on the economic consequences of IFRS adoption in Korea are more interesting than those from the results in European and Australian settings.

\section{A REVIEW OF LITERATURE}

In this section, we discuss empirical evidence on the economic consequences of IFRS adoption in Korea by providing a critical review on 18 selected empirical studies ${ }^{7}$. We use the term 'economic consequences' to denote the effects of financial reporting on firm values and the wealth of those who make or are affected by decisions based on accounting information, following Zeff (1978) and Holthausen and Leftwich (1983). Specifically, we organize our review around the following six dimensions with which to assess economic consequences of IFRS adoption in Korea: (1) earnings quality, (2) comparability of financial statements, (3) value relevance, (4) analysts' behavior, (5) information asymmetry, and (6) cost of capital and firm value.

\footnotetext{
${ }^{7}$ We focus on accounting literature published in leading accounting journals in Korea (Korean Accounting Review, Korean Accounting Journal, Accounting, Tax \& Auditing Research) and selected Korean Accounting Association conference papers.
} 


\section{Effects on Earnings Quality}

There are competing arguments regarding the effects of IFRS adoption on accounting quality. Some studies argue that financial statements prepared according to IFRS, as an internationally acceptable set of high quality financial reporting standards, provide superior quality accounting information compared with those prepared under local GAAP, because IFRS help to ensure a high degree of transparency and comparability of financial statements (Ashbaugh and Pincus 2001). On the contrary, others insist that IFRS, predominantly principles-based accounting standards, are likely to lower the quality of financial statements because the higher levels of managerial discretion in applying IFRS may cause hindrance of the financial statements comparability (Jeanjean and Stolowy 2008; Barth et al. 2008).

Several studies have examined the effects of IFRS adoption on accounting quality in Korea. Park et al. (2012) compare the firms' discretionary accruals in the adoption year (2011) and the year before (2010) to examine the effects of IFRS adoption on earnings quality. They find that discretionary accruals substantially decreased with the adoption of IFRS. Especially, discretionary accruals are significantly reduced for the sample firms with positive discretionary accruals before IFRS adoption. From these results, they argue that the adoption of IFRS improves the reliability of financial statements. Park et al. (2012) also investigate whether additional abnormal audit hours mitigate earnings managements. They find that upward earnings management decreases in abnormal audit hours, indicating that audit efforts become more important after the adoption of IFRS. Their study contributes to the literature in that it compares discretionary accruals before and after the mandatory adoption of IFRS for listed firms in Korea to investigate the effects on earnings quality of IFRS adoption. However, their study does not control for the different economic environment between 2010 and 2011. Hence, their findings are likely to suffer from an endogeneity problem due to omitted variables. Yu and Cha (2014) replicate the study of Park et al. (2012) by extending the sample period from 2009 to 2012. Their results are consistent with those of Park et al. (2012).

Choe and Son (2012) also examine the effect of IFRS adoption on accruals for the mandatory IFRS adopters. They employ a unique approach by analyzing the comparative financial statements prepared under IFRS and K-GAAP for 2009 and 2010, which are disclosed in the notes to the financial statements in $2011^{8}$. This approach may resolve the endogeneity issues in Park et al. (2011). Consistent with Park et al. (2011), their results show that discretionary accruals decrease after IFRS adoption, suggesting an improvement in earnings quality. Despite a potential sampling bias from the limited study period (2009-2010), this study contributes to the literature by providing empirical evidence after controlling for endogeneity problems.

Jeong (2013) evaluates changes in earnings quality by focusing on consolidated financial statements, rather than separate financial statements, after IFRS adoption. He uses the absolute values of firm-year discretionary accruals as a measure for earnings quality to overcome the likely endogeneity problem. He finds that the absolute value of discretionary accruals in separate financial statements decreases after IFRS adoption, indicating that the quality of accounting information in separate financial statements improves following the changes in accounting standards. However, the absolute value of discretionary accruals in consolidated financial statements increases in the post-IFRS adoption period. Jeong (2013) argues that the findings are interesting as the quality of separate financial statements information seems to be improved after IFRS adoption, while the results are not consistent in terms of consolidated financial statements perspectives. These results can be interpreted as follows. Because of the changes in primary financial statements from separate financial statements to consolidated financial statements after IFRS adoption, companies may have incentives to manage earnings through subsidiaries which are mainly unlisted firms. Otherwise, these results may be merely temporary phenomena resulting from the unfamiliarity of accountants and auditors with preparing consolidated financial statements under IFRS. Future studies should examine these potential differential effects of IFRS adoption on consolidated financial statements and separate financial statements.

Kim (2014) investigates whether IFRS adoption affects the association between auditors' quality (their ability and independence) and earnings management. Following Beck et al. (1998), he uses auditor size as a proxy for auditors'

\footnotetext{
${ }^{8}$ Considering the significant effects of IFRS on the financial position and financial performance of companies, there was a need to require companies to provide the users of the financial statements with information relating to the effects of IFRS adoption on the company in advance. Thus, the Financial Supervisory Service issued a practical guideline in July 2007 recommending that companies disclose the effects of IFRS adoption in the notes to the financial statements, starting from two years prior to the adoption. (IFRS Country Report, 2012)
}

Copyright by author(s); $\underline{\mathrm{CC}-\mathrm{BY}}$ 
quality. This study finds that the absolute value of discretionary accruals decreases after IFRS adoption and that this decrease in earnings management appears to be greater for the firms with Non-Big4 auditors. Kim (2014) argues that Big4 auditors are likely to already maintain high-quality control over their audit process, thereby limiting the impacts from IFRS adoption. Therefore, the effect of changes in accounting standards may be greater for Non-Big4 auditors. He also conducts several robustness tests, propensity score matching, mean centering process, and Newey-West tests, to deal with several endogeneity problems such as selection bias and yearly estimations of discretionary accruals addressed in Lawrence et al. (2011).

Overall, most studies examining the effects of IFRS adoption on earnings quality in Korea provide consistent evidence that earnings quality has improved following IFRS adoption. This is contrary to the mixed evidence from the studies in EU countries or Australia. This positive effect on earnings quality may be due to the extensive efforts and systematic preparations for IFRS adoption by the Korean government.

We provide the following suggestions for future research. First, there could be methodological issues in estimating earnings quality which may reduce the power of empirical tests in this type of research. Earnings quality could be measured with different approaches such as income smoothing (variances of earnings), earnings persistence, earnings response coefficients, conservatism, conditional conservatism (timeliness of loss recognition), liquidity and the principle of matching costs with revenues.

Second, further investigation into earnings quality in consolidated financial statements and separate financial statements could be an interesting topic for future research. In particular, firms' characteristics may affect the potential differences in earnings quality between consolidated financial statements and separate financial statements. For example, firms under the control of large shareholders or firms with a number of unlisted subsidiaries may emphasize the information in consolidated financial statements. Ownership-Control disparity issues could affect earnings management differently in consolidated financial statements and separate financial statements.

\section{Effects on the Comparability of Financial Statements}

The conceptual framework of IASB and IFRS states that the objective of financial reporting is to provide information about the reporting entity, which is useful to present and potential equity investors, lenders, and other creditors in making informed decisions. The conceptual framework distinguishes between two types of qualitative characteristics that are necessary to provide useful financial information: fundamental (relevance and faithful representation) and enhancing (comparability, timeliness, verifiability and understandability) characteristics. Among the enhancing qualitative characteristics, comparability is defined as the quality of information that enables users to identify similarities in and differences between two sets of economic phenomena. Thus, comparability is an important index to compare the qualities of financial statements across different companies and different periods for a given company. However, limited empirical studies exist on the effect of IFRS adoption on financial statements comparability, mainly due to the methodological issues involved in measuring comparability.

Choi et al. (2013) use the estimate suggested in De Franco et al. (2011) to measure the comparability of financial statements. Using a panel analysis, they compare the differences between the periods before (2009-2010) and after (2012-2013) the switch to IFRS. Their results show that the comparability of financial statements has improved following IFRS adoption. They attribute this result to the fact that firms in the same industry tend to use a similar accounting treatment under the principle-based approach of IFRS. Furthermore, the improvement in comparability is stronger for the companies with a large foreign ownership ratio.

Another issue regarding comparability after IFRS adoption involves the treatment of operating profit or loss. Whereas K-GAAP had been considered operating profit or loss as an important item, operating profit or loss is no longer required to be disclosed under IFRS. Consequently, accounting treatments for operating profit or loss varied considerably among companies: some did not disclose the information, some disclosed the information based on the rules specified in K-GAAP, and others arbitrarily determined the scope of operating profit or loss to their own needs (KASB 2012). 
Cheon and Ha (2011) address this issue by using voluntary IFRS adopters in Korea. They examine the status of disclosure, the method of measuring operating profit or loss and the motivation for these decisions. They find that the decision to disclose operating profit or loss varies across firms. Also, firms measure operating profit or loss in two different ways: (1) including all items, except financial income and financial expenses, in operating profit or loss, and (2) subtracting the costs of goods sold and selling, general and administrative expenses from sales. Early IFRS adopters favor the first method. Firms with Big4 auditors and smaller amounts of other items are likely to include other items in operating profit or loss. They argue that operating profit or loss information under IFRS may reduce the comparability of financial statements and cause confusion among financial statements users.

In an attempt to resolve the issue of disclosing operating profit or loss raised by Cheon and Ha (2011) and many domestic constituents, KASB decided that all companies under IFRS are required to disclose their operating profit or loss, either on the face of the statements of profit or loss and other comprehensive income or in the notes to the financial statements. KASB also required the companies to disclose in the notes the differences between the operating profit or loss under IFRS and under K-GAAP by adding a paragraph to K-IFRS 1001 'Presentation of Financial Statements'.

Lee et al. (2012) examine the factors that may adversely affect the comparability of financial statements under IFRS. Using semi-annual financial statements in the first year of IFRS adoption (2011), they find that the following four factors may lower the comparability: (a) the method of measuring operating profit or loss varies across firms, (b) firms do not fully disclose the details of other operating reverses and expenses, impairing comparability of operating profit or loss, (c) some firms prepare consolidated financial statements even when they hold less than $50 \%$ of the subsidiary's stock, and (d) the volume of notes disclosure increases from 25 pages to 60 pages on average after IFRS adoption, potentially impairing the readability of financial statements.

\section{Effects on Value Relevance}

The value relevance of accounting information is measured as the ability of earnings information and book values to explain market values of equity or changes in market values of equity. Accordingly, accounting information could be viewed as value relevant if it reflects a significant portion of the equity value or if it is significantly associated with changes in the equity value. Several studies have used the Ohlson (1995) valuation model to evaluate the effects of IFRS adoption on the comparability of financial information. In Ohlson (1995), the incremental value relevance of additional information on comparable groups such as industry yields implies lower comparability. In contrast, no incremental effects of value relevance indicate no significant changes in comparability. This result can be interpreted as higher comparability with higher value relevance, all other things being equal. Despite these theoretical findings, few empirical studies have tested these hypotheses in the literature because value relevance in two different periods may be affected by external factors such as history effects, which are difficult to control for.

However, Korean firms were required to disclose changes in financial statements with the adoption of IFRS, and thus the effects of IFRS adoption on value relevance can be analyzed without suffering from these methodological problems. In particular, the first-time adoption of IFRS in Korea was set out under Korean IFRS 1101, Firstly Adoption of International Financial Reporting, which requires the application of same accounting policies to statement of financial position and for the periods when the comparative financial statements are disclosed (KASB 2012). The aim of this requirement is to increase the comparability of financial statements by helping information users to understand the items affected by differences in IFRS and K-GAAP. Hence, notes to financial statements in 2011 include financial statements of 2010 which are re-prepared under IFRS. Therefore, the financial statements of 2010 could be used to directly compare the effects of two different accounting standards, K-GAAP and IFRS, for the same firm (KASB 2012).

Using this comparative accounting information, Choi (2013) compares the value relevance of financial statements information prepared under K-GAAP and IFRS separately. He finds an absence of any significant difference in value relevance of both book value of equity and net income under K-GAAP and IFRS. Also, the difference between book value of equity under IFRS and K-GAAP is negatively correlated with stock prices. However, this negative association 
does not hold for net income. He concludes that net income under IFRS does not provide additional information to net income under K-GAAP, suggesting that IFRS adoption may not improve the comparability of financial statements.

Choi et al. (2013) attempt to overcome the limitations suggested in Choi (2013). They analyze value relevance using financial statements information for the year preceding IFRS adoption, but prepared under both K-GAAP and IFRS. They test whether accounting values reported under IFRS provide additional value relevance to those reported under K-GAAP. They find that net income under IFRS has incremental value relevance over net income under K-GAAP, but the opposite results are presented in the case of book value of equity. This study contributes to the existing literature by providing evidence based on the data which may control for the endogeneity issues.

The information prepared in the year preceding IFRS adoption using IFRS has a limitation because it is disclosed only in the notes to the annual financial statements. Furthermore, financial statements information prepared using IFRS in the year preceding IFRS adoption is only available in the adoption year with one-year comparison data. Nonetheless, one of the advantages in Korean firm data is that financial statements reported under both K-GAAP and IFRS for the year preceding IFRS adoption are available and they can be used to mitigate the endogeneity problems inherent in the studies of potential effects of IFRS adoption.

\section{Effects on Analysts' Behavior}

Financial analysts are widely acknowledged to play an important role by processing and interpreting publicly available accounting information as well as creating and disseminating new information. Therefore, analysts' forecasts data are an important part of the information environment in capital markets that affect the behavior of both investors and management (Beyer et al. 2010). Research on the changes in analysts' behavior after IFRS adoption can provide an insight into the effect of IFRS adoption on information environment (Byard et al. 2011). Analysts' forecasts provide an excellent way to evaluate the effects of IFRS adoption because they not only reflect the overall quality of financial statements information available to them, but are also a good proxy for investors' belief, which may not be directly measured (Arbarbanell et al. 1995).

There is limited empirical evidence in Korea as to the economic consequences of IFRS adoption from the perspective of analysts' behavior. It is unclear how IFRS adoption affects analysts' information environment. IFRS adoption may improve analysts' information environment by increasing disclosure and transparency or by enhancing the comparability of financial statements. However, if IFRS are suboptimal relative to firms' domestic accounting standards in reflecting firm performance, IFRS adoption may render financial reporting less informative, thereby reducing the quality of analysts' information. In addition, earnings may become more volatile and thus more difficult to forecast under IFRS. Hence, it is equally probable that mandatory IFRS adoption may have little impact on analysts' information environment.

Yu and Cha (2014) investigate the effects of IFRS adoption on analysts' behavior by examining how errors in analysts' earnings forecasts change after the adoption of IFRS. Their results show the decreases in both analysts' forecasts errors and their variances following IFRS adoption. They argue that this result may be due to the improvement in accounting information quality under IFRS, which provides more enhanced information environment for analysts.

Choe and Son (2011) analyze the effects of asset revaluation under IFRS on analysts' forecasts. They find that analysts' earnings forecasts accuracy is positively associated with asset revaluation of IFRS. That is, analysts report more accurate earnings forecasts for the firms with asset revaluation under IFRS. Their finding suggests that fair value measurement and its disclosure, followed by asset revaluation, enhance the usefulness of accounting information, and hence reduce information asymmetry between firms and financial statements users. Contrary to the concern that fair value accounting may impair the reliability of accounting information, this result supports the argument that fair value measurement of assets produces more relevant and useful information.

Overall, IFRS adoption seems to have enhanced analysts' earnings forecasts accuracy in Korea. However, this conclusion is based on limited empirical evidence and controversy continues as to whether IFRS adoption improves accounting information environment. Therefore, more research in this area is necessary to resolve this issue. 


\section{Effects on Information Asymmetry}

IFRS has been adopted by over 150 countries with the purpose of improving financial reporting quality and decreasing information asymmetry among capital market participants within and across countries by reducing information processing costs. A decrease in information asymmetry would lower the information risk for investors, and eventually the cost of capital. Accordingly, given that one of the major incentives for Korea's decision to fully adopt IFRS was to decrease the 'Korea discount' phenomenon, the effects of IFRS adoption on information asymmetry are very important (Leuz and Verrecchia, 2000).

Shin and Choi (2014) examine the effects of IFRS adoption on information asymmetry using a comprehensive sample of Korean firms that have been consecutively listed for 7 years from 2006 to 2012. They analyze the effects of IFRS adoption on information asymmetry and stock price synchronicity. Information asymmetry is measured by quoted spread and effective spread suggested by Bessenbinder (2003). A synchronicity level variable is used to measure stock price synchronicity following Jin and Myer (2006). Their empirical results show that both information asymmetry and stock price synchronicity decrease in the post-IFRS period (2011-2012), suggesting that IFRS may provide more information with high quality.

Kim and Cho (2014) also provide similar empirical evidence regarding the effect of IFRS adoption on information asymmetry. They use the standard deviation of daily stock returns to measure information asymmetry. Their results show that information asymmetry decreases from the pre-IFRS (2009) to post-IFRS (2012) periods.

Overall, these studies report consistent empirical evidence that information asymmetry decreases following IFRS adoption. However, they examine relatively short periods of time and still suffer the omitted variables problem.

\section{Effects on Costs of Equity Capital and Firm Value}

Lambert et al. (2007) argue that the quality of accounting information influences a firm's cost of capital both directly and indirectly as accounting information affects market participants' perceptions regarding the distribution of the firm's future cash flows. IFRS is expected to reduce the cost of capital by increasing the quality of financial disclosure and enhancing financial statements comparability. Covrig et al. (2007) document evidence that a single set of accounting standards such as IFRS can improve the comparability of financial information of firms across capital markets, by allowing the investors to use less costly information, and reducing information asymmetry, which decreases the cost of capital.

Kim and Cho (2014) provide a comprehensive analysis on the effects of IFRS adoption on the cost of equity capital, cost of debt capital and firm value measured by Tobins' q. They report that the adoption of IFRS in Korea lowers the cost of equity capital, lowers the cost of debt capital and increases firm value. They argue that the results suggest that IFRS have been not only been successfully implemented, but have also positively affected the capital market in Korea.

$\mathrm{Yu}$ and Cha (2014) provide a comprehensive study on IFRS adoption in Korea by investigating its effects on the quality of financial statements, changes in information environment, and other economic consequences. They examine the effects of IFRS adoption on discretionary accruals and real earnings management. They also test incremental information effect of separate financial statements by comparing the value relevance of financial statements between pre- and post-IFRS adoption periods. In addition, they examine the effects of IFRS adoption on analysts' forecasts accuracy and bias. Finally, they investigate the changes in cost of capital after IFRS adoption.

Their results show that discretionary accruals and real earnings management decrease after IFRS adoption, that the value relevance of accounting information under IFRS is greater than under K-GAAP, and that analysts' earnings forecast accuracy increases significantly. Consistent with these results, the cost of capital decreases after IFRS adoption. Moreover, these effects are stronger for the firms with sound corporate governance or increased financial disclosures. Overall, the cost of equity capital has decreased after IFRS adoption, suggesting that Korean capital market may benefit from IFRS adoption. 
However, international empirical evidence provides mixed results. Using a comprehensive sample of 1,084 firms in the EU from 1995 to 2006, $\mathrm{Li}$ (2010) find that the average cost of capital decreases from $9.24 \%$ to $8.77 \%$ for the mandatory IFRS adopters in the EU. Kim and Shi (2012) also examine the changes in the cost of capital after IFRS adoption for 21,608 firms from 34 countries. They report that the cost of equity capital significantly decreases after IFRS adoption regardless of corporate governance or enforcement across countries. However, the decrease in the cost of equity capital is larger for the firms in countries with weak legal enforcement system. In contrast, Lee et al. (2008) report that the cost of equity capital may not decrease after IFRS adoption in countries with relatively lower incentives for financial reporting. Furthermore, Gordon et al. (2012) find that foreign direct investment (FDI) increases with IFRS adoption in emerging market countries where capital markets are not well developed. This means that IFRS adoption would not have a positive effect on FDI in developed capital markets. In this regard, the Korean capital market, with its greater home bias, may benefit more from IFRS adoption than the markets of European countries. Moreover, country characteristics such as legal system, legal enforcement, and the difference between local GAAP and IFRS may affect the successful implementation of IFRS. Future research should focus on these country characteristics in examining the effects of IFRS adoption. An appendix Table 3 summarizes the studies that examine the effects of IFRS adoption and offers future research directions.

\section{CONCLUDING REMARKS}

This study provides a comprehensive review of the literature on the economic consequences of IFRS adoption in Korea, along with suggestions for future research. We organize our review into six areas: (1) earnings quality, (2) comparability of financial statements, (3) value relevance, (4) analysts' behavior, (5) information asymmetry, and (6) cost of capital and firm value. The results arising from our review can be summarized as follows:

First, the adoption of IFRS is likely to affect the overall accounting system in Korea. Studies on the effects of IFRS adoption on earnings quality report consistent empirical evidence that IFRS improve the quality of accounting information, whereas international literature provides mixed results.

Second, in spite of limited studies on the effect of IFRS on the comparability of financial statements, the existing studies suggest that firms in the same industry are likely to apply similar accounting treatment for the financial reporting under IFRS, and thus that IFRS adoption has enhanced the comparability. This is contrary to the mixed results in other countries. In an attempt to resolve the ambiguity in the standard regarding operating profit or loss and to improve comparability of financial statements, KASB decided to require companies to disclose operating profit or loss under IFRS. This may provide useful insights to the countries that focus on operating profit or loss information.

Third, similar to previous studies in other IFRS adopters, Korean studies also show mixed results regarding the effects of IFRS adoption on the value relevance. This may be due to the methodological issues arising from the short period of time that is available to test the effect of IFRS adoption.

Fourth, empirical results show that analyst forecast accuracy increases and its variance decreases in the post-IFRS adoption period, indicating that IFRS adoption in Korea improves the information environment for analyst forecasts.

Fifth, Korean studies show that the information asymmetry decreases after IFRS adoption, indicating that the overall capital market environment has been improved in terms of decreased home bias, agency problem, and information asymmetry between major and minor shareholders.

Finally, evidence shows that the cost of equity capital has decreased after IFRS adoption, suggesting that Korean firms are likely to benefit from IFRS adoption.

Overall, Korean studies provide evidence that IFRS adoption plays a positive role in Korean capital market and that IFRS have led to improvements in financial reporting and overall accounting environment. Given that enforcement may play an important role in determining the effectiveness of accounting standards, the potential benefits of IFRS adoption tend to vary among countries, which reflect differences in their enforcement regimes. As the accounting system is a complementary component of the country's overall institutional system, we expect that research on IFRS 
adoption in Korea will provide insights and be of interest to regulators in countries considering or in the process of adopting IFRS, especially countries with a similar institutional environment to Korea's.

However, concrete conclusions cannot be offered because of the limitations in the studies. For example, all existing studies use the samples obtained from only one or two years after the adoption of IFRS. Furthermore, some studies fail to address the endogeneity problems intrinsic in the approach of comparing the effects before and after IFRS without controlling for history effects. The mixed results regarding IFRS adoption in Korea may be related to these methodological issues. We may gain different findings as IFRS are taking root in Korea, more data are accumulated, and new methodologies are used in future studies.

The following suggestions for future research are presented. First, most studies that examine the association between IFRS adoption and earnings quality use accruals-based earnings management as a proxy for earnings quality. However, after the Sarbanes-Oxley Act, accrual-based earnings management has been significantly decreased and substituted by real earnings management. Therefore, further research on the tendency for a trade-off between accrualbased earnings management and real earnings management across countries in pre- and post-IFRS adoption periods may provide additional insights into the effects of IFRS adoption on earnings quality.

Second, as only a few studies have examined whether IFRS adoption has an impact on the comparability of financial statements, further research on this issue is needed. In particular, Korean evidence in this area may be interesting to the countries such as Japan and the U.S. where operating profit or loss is perceived to be a very important performance measure. Future research may also address the comparability issue by comparing the comparability across countries because of the regulatory and cultural differences.

Third, financial statement users may require a certain amount of time to accumulate know-how and experience under new accounting standards. As most studies use a short period of time to examine the impact of IFRS on value relevance, future research from a more extended vantage point will be able to use longer periods to better observe potential changes in value relevance from pre-IFRS to post-IFRS periods.

Fourth, it would be interesting to explore the differences in the analysts' forecast accuracies and analysts' followings between domestic analysts and foreign analysts after IFRS adoption. This may afford better understanding of whether IFRS reduce home bias.

Fifth, future research into the effects of IFRS adoption on information asymmetry should use longer study periods, different measures of information asymmetry suggested by Frankel et al.(2006), and different methods (e.g., BKLS model suggested by Barron et al. (2008)) to examine the use of private information by analysts and the changes in information asymmetry over time.

Sixth, future studies can extend the research into the effects on the cost of capital and firm value by investigating the changes in FDI after IFRS adoption.

Finally, our review indicates that some economic consequences of IFRS adoption in Korea differ from those in other countries. This may be due to differences in national characteristics such as legal systems, law enforcement, capital market development and accounting systems across countries. Thus, future research should address the relationship between national characteristics and the different effects of IFRS adoption. 


\section{ACKNOWLEDGMENTS}

This work was supported by the Ministry of Education of the Republic of Korea and the National Research Foundation of Korea (NRF-2016S1A5A8018398)

\section{AUTHOR BIOGRAPHIES}

Jang, Jee In, Ph.D., Chair, Korea Accounting Standards Board and Professor, Chung-Ang University, Seoul, Republic of Korea. E-mail address: jjang@kasb.or.kr (Main Author)

Lee, Kyung Joo, Ph.D., Professor, Department of Business, Management and Accounting, University of Maryland at Eastern Shore, MD U.S.A.

Seo, Youngmi, Ph.D., Technical Manager, Korea Accounting Standards Board, Seoul, Republic of Korea, E-mail address: ymseo@kasb.or.kr.

Cheung, Joonhei, Ph.D., Assistant Professor, Department of Accounting, Daegu University' Gyeongsanbuk-do, Republic of Korea. E-mail address: janny81@daugu.ac.kr (Corresponding author)

\section{REFERENCES}

Ahmed, A., M. Neel, \& D. Wang. 2013. Does Mandatory Adoption of IFRS Improve Accounting Quality? Preliminary Evidence. Contemporary Accounting Research 30(4): 1344-1372.

Arbarbanell, J., W. Lanen \& R. Verrecchia. 1995. Analysts' Forecasts as Proxies for Investors' Beliefs in Empirical Research. Journal of Accounting and Economics 20(1): 31-60.

Armstrong, C., M. Barth, A. Jagolinzer, and E. Riedl. 2012. Market Reaction to the Adoption of IFRS in Europe. The Accounting Review 85: 31-61.

Ashbaugh, H., \& M. Pincus, 2001. Domestic Accounting Standards, International Accounting Standards, and the Predictability of Earnings. Journal of Accounting Research 39(3): 417-434.

Bae, K., H. Thn, and M. Welker. 2008. International GAAP Differences: The impact on foreign analysts. The Accounting Review 83(3): 593-628.

Banker, R., \& L. Chen. 2006. Predicting Earnings Using a Model Based on Cost Variability and Cost Stickiness. The Accounting Review 81(2): 285-307.

Barron, O. E., Byard, D., \& Yu, Y. 2008. Earnings Surprises that Motivate Analysts to Reduce Average Forecast Error. The Accounting Review 77: 821-846.

Barth, M., W. Landsman, \& M. Lang. 2008. International Accounting Standards and Accounting Quality. Journal of Accounting Research 46(3): 467-498.

Becker. C., Defond. M. Jiambalvo, J, \& Subramanyam. 1998. The Effect of Audit Quality on Earnings Management. Contemporary Accounting Research 15(1): 1-24.

Bessenbinder, H. 2003. Issues in Assessing Trade Execution Costs. Journal of Financial Markets 6(1): 233-257.

Beyer A., D. A Chen, L. Thomas, \& B. R. Walter. 2010. The Financial Reporting Environment: Review of the Recent Literature. Journal of Accounting \& Economics. 50: 296-343.

Brown. P., J. Preiato, \& A. Tarca. 2014. Measuring country differences in enforcement of accounting standards: An audit and enforcement proxy, Journal of Business Finance \& Accounting 41(1): 1-52.

Burnett, B. M., B. M. Cripe, G. W. Martin, \& B. P. McAllister. 2012. Audit Quality and the Trade-off between Accretive Stock Repurchases and Accrual-based Earnings Management. The Accounting Review 87: 1861-1884.

Byard, D., Y. Li, \& Y. Yu. 2011. The Effect of Mandatory IFRS Adoption on Financial Analysts' Information Environment. Journal of Accounting Research 49: 69-96.

Capkun, V., A. C. Jeny. T. Jeanjean, \& L. A. Weiss. 2008. Earnings management and value relevance during the mandatory transition from local GAAPs to IFRS in Europe. Working paper.

Cascino, S. \& J. Gassen. 2015. What Drives the Comparability Effect of Mandatory IFRS Adoption?. Review of Accounting Studies 20(1): 242-282.

Cheon, Y. S., \& Ha, S. H. 2011. Disclosure and Classification of Operating Income by Firms that Early Adopt K-IFRS. Korean Accounting Journal 20(2): 239-275. [Printed in Korean]

Cheon, Y. S., \& Jung, D. J. 2009. Stock Market Response to the Mandatory Adoption of IFRS. Accounting, Tax \& Auditing Research 49(1): 241-281. [Printed in Korean]

Choi, J. H. 2013. The Adoption of IFRS and Value Relevance of Accounting Information. Korean Accounting Review 38(1): $391-424$. [Printed in Korean]

Copyright by author(s); $\underline{\mathrm{CC}-\mathrm{BY}}$ 
Choi, K. H., \& Son, Y. J. 2012. The Effects of K-IFRS Adoption on the Financial Statements Items, Financial Ratios, and Accruals. Korean Accounting Journal 21(6): 209-256. [Printed in Korean]

Choi, Y. S., Yang, D. H., \& Cho, K. H. 2014. K-IFRS Adoption and Accounting Comparability. Working paper. Korean Accounting Association Conference [Printed in Korean]

Clarkson. P., H. D. Hanna, G. D. Richardson, \& R. Thompson, 2011, The Impact of IFRS Adoption on the Value Relevance of Book Value and Earnings. Journal of Contemporary Accounting \& Economics, 1-17.

Covrig, V., DeFond, M., \& Hung, M. 2007. Home Bias, Foreign Mutual Fund Holdings, and the Voluntary Adoption of International Accounting Standards. Journal of Accounting Research 45(1): 41-70.

Daske, H., L. Hail, C. Leuz, \& R. Verdi, 2008. Mandatory IFRS Reporting around the World: Early Evidence on the Economic Consequences. Journal of Accounting Research 46(5): 1085-1142.

Daske, H., L. Hail, C. Leuz, \& R. Verdi, 2013. Adopting a Label: Heterogeneity in the Economic Consequences around IAS/IFRS Adoptions. Journal of Accounting Research 51(3). 495-547.

De Franco, G., S. P. Kothari, \& R. S. Verdi. 2011. The Benefits of Financial Statement Comparability. Journal of Accounting Research 49(4): 895-931.

Frankel. R, S. P. Kothari, \& J. Weber. 2006. Determinants of Informativeness of Analyst Research. Journal of Accounting and Economics 41: 29-54.

Holthausen, R. W. \& Leftwich, R. W. 1983. The Economic Consequences of Accounting Choice: Implications of Costly Contracting and Monitoring. Journal of Accounting and Economics 5: 77-117.

Houqe. M., T. Zijl, K. Dunstan, \& A. K. M. W. Karim, 2012, The Effect of IFRS adoption and investor protection on earnings quality around the world, The International Journal of Accounting 47, 333-355.

Houqe, N., van Kesteren, M. \& P. Clarkson, 2013. Understanding IFRS adoption: A Review of Current Debate and Consequences. Working paper: Victoria University of Wellington.

Jeanjean, T. \& H. Stolowy. 2008. Do Accounting Standards Matter? An Exploratory Analysis of Earnings Management before and after IFRS Adoption. Journal of Accounting and Public Policy 27(6): 480-494.

Jeong, T. B. 2013. Adoption of IFRS and Earnings Management. Korean Accounting Journal 22(1): 327-428. [Printed in Korean]

Jin, L., \& Myers, S. 2006. R² around the World: New Theory and New Tests. Journal of Financial Economics 79: 257-292.

Kaufmann, D., A. Kraay, \& M. Mastruzzi. 2009. Governance matters VIII: Governance indicators for 1996-2008. World Bank Policy Research. Washington, D.C.

Kim, K. T. 2014. The Association between K-IFRS Adoption and Earnings Management: Focusing on External Auditor Size. Accounting, Tax \& Auditing Research 56(1): 117-146. [Printed in Korean]

Kim, Y. S., \& Cho, S. M. 2014. The Economic Consequences of Financial Reporting under K-IFRS. Korean Accounting Journal 23(2): 73-103. [Printed in Korean]

Lambert, R., Leuz, C., \& Verrecchia, R. 2007. Accounting Information, Disclosure, and the Cost of Capital. Journal of Accounting Research 45(2): 385-420.

Lang, M., M. Maffett \& E. Owens. 2010. Earnings Comovement and Accounting Comparability: The Effects Mandatory IFRS Adoption. Working paper.

Lawrence, A., M. Minutti-Meza, \& P. Zhang. 2011. Can Big4 versus Non-Big4 Differences in Audit Quality Proxies be Attributed to Client Characteristics? The Accounting Review 86(1): 259-286.

Lee, H. Y., Kang, M. J., Chang, G. J., \& Lee, H. Y., 2012. An Analysis on Comparability of Financial Statements after IFRS Adoption. Korean Accounting Journal 21(3): 307-342 [Printed in Korean]

Leuz, C., \& R. Verrecchia. 2000. The Economic Consequences of Increased Disclosure. Journal of Accounting Research 38: 91-124.

Li. S. 2010. Does Mandatory Adoption of International Financial Reporting Standards in the European Union Reduce the Cost of Equity Capital? The Accounting Review 85 (2): 607-636.

Ohlson, J. 1995. Earnings, Book Values, and Dividends in Equity Valuation. Contemporary Accounting Research 11(2): 661-687.

Park, H. Y., Lee, H. Y., \& Kang, M. J. 2012. The Impact of IFRS Adoption on Earnings Management and Audit Hours. Accounting, Tax \& Auditing Research 54(2): 529-564. [Printed in Korean]

Shin, S. N., \& Choi, K. 2013. The Effect of K-IFRS Adoption on Information Asymmetry and Stock Price Synchronicity. Korean Accounting Association Annual Meeting [Printed in Korean]

Soderstrom, N., \& K. Sun, 2007, IFRS adoption and accounting quality: A Review, European Accounting Review 16, 675-702.

Tan, H., S. Wang, \& M. Welker. 2011. Analyst following and forecast accuracy after mandated IFRS adoptions. Journal of Accounting Research 49 (5): 1307-1357.

Yamaji, N., Hudson, J., \& Schneider, D. K. 2012. IFRS Adoption in Japan: Road Map and Challenges. 5(1)

Yip, W. Y., and Young, D. 2012. Does IFRS Adoption Improve Cross-border Information Comparability?. The Accounting Review 87(5): 1767-1789.

Yu, Y. G., \& Cha, S. M. 2014. The Effect and Economic Consequences of IFRS Adoption in Korea. Working paper. Financial Supervisory Service Symposium [Printed in Korean]

Zang, A. 2012. Evidence on the Trade-off between Real Activities Manipulation and Accrual-based Earnings Management. The Accounting Review 87(2): 675-703.

Zeff, S. A. 1978. The Rise of 'Economic Consequences', Journal of Accountancy 146(December): 56-63. 


\section{APPENDIX}

Summary of Studies on the Effects of IFRS Adoption and Future Research Directions

\begin{tabular}{|c|c|c|c|}
\hline Effects on & Studies & Results & Future research \\
\hline $\begin{array}{l}\text { Earnings } \\
\text { quality }\end{array}$ & $\begin{array}{l}\text { Choe and Son (2012) } \\
\text { Park et al. (2012) } \\
\text { Jeong (2013) } \\
\text { Kim (2013) } \\
\text { Yu and Cha (2014) }\end{array}$ & $\begin{array}{l}\text { Improvements in earnings quality: } \\
\text { - Decrease in discretionary accruals } \\
\text { - Auditors' efforts become more } \\
\text { important } \\
\text { - Smaller discretionary accruals from } \\
\text { financial statements prepared by } \\
\text { IFRS than K-GAAP } \\
\text { - Decrease in discretionary accruals is } \\
\text { larger for firms with Non-Big4 } \\
\text { auditors }\end{array}$ & $\begin{array}{l}\text { - Examine the tendency of the } \\
\text { tradeoff between accrual-based } \\
\text { earnings management and real } \\
\text { earnings management across } \\
\text { countries } \\
\text { - Use different proxy for earnings } \\
\text { quality from discretionary accruals } \\
\text { such as prior period adjustments } \\
\text { and Book and Tax income } \\
\text { difference (BTD) }\end{array}$ \\
\hline $\begin{array}{l}\text { Comparability } \\
\text { of financial } \\
\text { statements }\end{array}$ & $\begin{array}{l}\text { Cheon and } \mathrm{Ha}(2011) \\
\text { Lee et al. (2012) } \\
\text { Choi et al. (2013) }\end{array}$ & $\begin{array}{l}\text { Mixed results: } \\
\text { - Reduced comparability due to the } \\
\text { lack of standards on disclosure of } \\
\text { operating income } \\
\text { - Improved comparability after the KASB } \\
\text { requirement of operating income } \\
\text { - Many factors adversely affect the } \\
\text { comparability }\end{array}$ & $\begin{array}{l}\text { - Employ the comparability model } \\
\text { suggested by Cascino and Gassen } \\
\text { (2015) to control for the } \\
\text { endogeneity problem } \\
\text { - Examine the factors (regulation, } \\
\text { culture, home bias) affecting the } \\
\text { differential effects on the } \\
\text { comparability across countries }\end{array}$ \\
\hline $\begin{array}{l}\text { Value } \\
\text { relevance }\end{array}$ & $\begin{array}{l}\text { Choi (2013) } \\
\text { Choi et al. (2013) } \\
\text { Kim et al. (2014) }\end{array}$ & $\begin{array}{l}\text { No effects } \\
\text { - No significant difference in value } \\
\text { relevance of both book value of equity } \\
\text { and net income between K-GAAP and } \\
\text { IFRS } \\
\text { - No difference in value relevance } \\
\text { between consolidated and separate } \\
\text { financial statements under IFRS. } \\
\text { However, there exists incremental } \\
\text { value relevance between them }\end{array}$ & $\begin{array}{l}\text { - Replicate the study by using longer } \\
\text { periods } \\
\text { - Search for the reasons why the } \\
\text { improvement in earnings quality } \\
\text { does not result in the increase in } \\
\text { value relevance }\end{array}$ \\
\hline $\begin{array}{l}\text { Analysts' } \\
\text { behavior }\end{array}$ & $\begin{array}{l}\text { Choe and Son (2011) } \\
\text { Yu and Cha (2014) }\end{array}$ & $\begin{array}{l}\text { Enhanced information environment } \\
\text { for analysts } \\
\text { - Decrease in both analysts' forecasts } \\
\text { error and their variance } \\
\text { - Analysts provide more accurate } \\
\text { earnings forecasts for the firms with } \\
\text { assist revaluation under IFRS }\end{array}$ & $\begin{array}{l}\text { - Investigate the differences in } \\
\text { forecast accuracy between } \\
\text { domestic and foreign analysts after } \\
\text { IFRS adoption } \\
\text { - Compare the members of domestic } \\
\text { and foreign analysts following the } \\
\text { firms }\end{array}$ \\
\hline $\begin{array}{l}\text { Information } \\
\text { asymmetry }\end{array}$ & $\begin{array}{l}\text { Kim and Cho (2014) } \\
\text { Shin and Choi (2014) }\end{array}$ & $\begin{array}{l}\text { Decrease in information asymmetry } \\
\text { - Both quoted spread and effective } \\
\text { spread decrease } \\
\text { - Decrease in the standard deviation of } \\
\text { daily stock returns } \\
\text { - Decrease in stock price synchronicity }\end{array}$ & $\begin{array}{l}\text { - Use longer periods in the analysis } \\
\text { - Analyze information asymmetry } \\
\text { issue using the ACCRSQ model of } \\
\text { Frankel et al.(2006) } \\
\text { - Employ the BKLS model to } \\
\text { examine the financial analysts' use } \\
\text { of private information and the } \\
\text { changes in information asymmetry }\end{array}$ \\
\hline $\begin{array}{l}\text { Costs of } \\
\text { capital and } \\
\text { firm value }\end{array}$ & $\begin{array}{l}\text { Cheon and Cheong (2009) } \\
\text { Kim and Cho (2014) } \\
\text { Yu and Cha (2014) }\end{array}$ & $\begin{array}{l}\text { Decrease in cost of capital and } \\
\text { increase in firm value } \\
\text { - Abnormal returns on the good news } \\
\text { of IFRS adoption } \\
\text { - Decrease in cost of equity capital } \\
\text { - Increase in Tobin's Q }\end{array}$ & $\begin{array}{l}\text { - Examine the changes in foreign } \\
\text { direct investments after IFRS } \\
\text { adoption } \\
\text { - Test the differential effects on the } \\
\text { cost of capital and firm value } \\
\text { between the firms with higher } \\
\text { information asymmetry and those } \\
\text { with lower information asymmetry }\end{array}$ \\
\hline
\end{tabular}

